\title{
The corrosion inhibition of mild steel in sulphuric acid solution by flavonoid (catechin) separated from Nypa fruticans Wurmb leaves extract
}

\author{
Nwaugbo Chinenye Michael, James Abosede Olubunmi* \\ Department of Pure and Industrial Chemistry, Faculty of Chemical Sciences, University of Port Harcourt, P.M.B. 5323, Port Harcourt, Rivers \\ Sate, Nigeria
}

\section{Email address:}

mikejahson@yahoo.co.uk (C. M. Nwaugbo), bidean2002@yahoo.com (A. O. James)

\section{To cite this article:}

Nwaugbo Chinenye Michael, James Abosede Olubunmi. The Corrosion Inhibition of Mild Steel in Sulphuric Acid Solution by Flavonoid (Catechin) Separated from Nypa Fruticans Wurmb Leaves Extract. Science Journal of Chemistry. Vol. 2, No. 4, 2014 , pp. 27-32.

doi: $10.11648 /$ j.sjc.20140204.11

\begin{abstract}
The corrosion inhibition of mild steel in sulphuric acid by flavonoids, separated from Nypa fruticans Wurmb leaves extract was studied using weight loss technique at $303 \mathrm{~K}, 313 \mathrm{~K}, 323 \mathrm{~K}, 333 \mathrm{~K}$ and $353 \mathrm{~K}$,. The constituents were separated by fractionation using Soxhlet apparatus after room temperature extraction with $70 \%$ acetone. The constituents were identified using standard functional group analysis (phytochemical screening) methods. The inhibitor concentrations of $0.1 \mathrm{~g} / \mathrm{L}, 0.2 \mathrm{~g} / \mathrm{L}$, $0.3 \mathrm{~g} / \mathrm{L}, 0.4 \mathrm{~g} / \mathrm{L}$ and $0.5 \mathrm{~g} / \mathrm{L}$ were used in $0.1 \mathrm{M}, 0.5 \mathrm{M}, 1 \mathrm{M}$ and $2 \mathrm{M}$ concentrations of acid solutions. Inhibition efficiency increased with increase in temperature and inhibitor concentration. Thus, maximum inhibition efficiency of $74.48 \%$ was obtained at the optimum temperature $(323 \mathrm{~K})$ and concentration $(0.5 \mathrm{~g} / \mathrm{L})$ for the flavonoid constituent. The flavonoid (catechin) separated from Nypa fruticans Wurmb leaves extract were used separately as efficient corrosion inhibitor of mild steel in $\mathrm{H}_{2} \mathrm{SO}_{4}$.
\end{abstract}

Keywords: Corrosion, Inhibition, Nypa Fruticans Wurmb, Flavonoid, Mild Steel, Weight Loss, Sulphuric Acid

\section{Introduction}

Corrosion of metals and their alloys such as iron and steel due to exposure to acid and alkaline media results in in mechanical failure of equipment due to their exposure to acidic and alkaline media. This is mediated by the use of corrosion inhibitors, which are usually added in minute quantities, to slow down the rate of corrosion of the metal or metal alloy [1]. Most of the compounds currently used as corrosion inhibitors are toxic, non-biodegradable and costly to synthesize [2]. This led to the search for and use of alternative sources of corrosion inhibitors that are eco-friendly. Plant extracts are renewable sources of materials that are environmentally safe, readily available and inexpensive [3]. Therefore they have advantages over the synthetic corrosion inhibitors. Use of plant extracts as corrosion inhibitors in acid and alkaline media have been reported [1, 4-13].

This study investigates the use of flavonoids (catechin), separated from Nypa fruticans Wurmb leaves extract, as an effective corrosion inhibitor on mild steel in sulphuric acid solution.
Nipa (Nypa Fruticans Wurmb) is believed to be one of the oldest and most extensively cultivated palm in the world, originally from India, Sri Lanka, the Philippine islands and some other islands of the Pacific. It was imported to Nigeria in 1906 as one of the ecological implications of colonization. Nypa fruticans Wurmb is of the family Arecaceae (palmae), the only palm species from mangrove areas and is adapted to muddy soils along rivers and estuaries. It usually grow underground stem which branches to form new above-ground plants. Non-economic (ecological) benefits of Nipa Palm include use as a buffer crop for ecosystems like mangrove plants, holding soil erosion on the banks of river discharge and resist abrasion caused by wind and tides [14], Nipa forest serving as a nursery ground for some types of fish and shrimp [15]. While Economic benefits of Nipa Palm include: use of young shoots, decayed wood and buried roots or leaves as medicine in various parts of South Asia. It is used for herbs to cure toothache and headache. The sap is used as a source of sugar to produce vinegar and alcoholic beverages in the Philippines and Malaysia [16]. Its old leaves are used for thatching or roofing houses while Nipa seeds are used as tasty desserts [17], and as heavy metal adsorbents [18]. 
It has been observed that Nipa is a highly opportunistic species, a trait helped by the fact that much of the mangrove forest of Nigeria and Cameroon is being felled to provide wood fuel for commercial smoked fish [19]. Its fast growing tendency is a continual threat to the more useful mangrove forest, as well as water ways and marine lives; hence the call by some quarters for its eradication [20,21].

Previously reported research works done on the use of Nypa Fruticans extract were: [10, 22 - 24], where crude extract of the leaves were used as corrosion inhibitor. There is no reported work on "the corrosion inhibition of flavonoids (catechin), separated from Nypa fruticans Wurmb leaves extract, on mild steel in sulphuric acid solution". However, the use of flavonoid (catechin) from Peanut skin for corrosion inhibition of mild steel in hydrochloric acid solution has been reported [25].

\section{Experimental}

\subsection{Preparation of Mild Steel Coupons}

Mild steel sheet obtained from the Engineering Workshop of the University of Port Harcourt, Rivers State, of approximate composition; $0.120 \% \mathrm{C}, 0.900 \% \mathrm{Mn}, 0.066 \% \mathrm{~S}$, $0.050 \% \mathrm{P}, 0.100 \% \mathrm{Si}$, and $98.314 \% \mathrm{Fe}$, of thickness $2 \mathrm{~mm}$ was cut into rectangular coupons of dimensions $25 \mathrm{~mm}$ x $20 \mathrm{~mm}$. The coupons, drilled at the centre for passage of rubber thread, were mechanically polished to obtain a clean shiny surface, washed in deionized water, degreased in ethanol, dried in acetone and then stored in moisture free desiccator for subsequent use.

\subsection{Preparation and Separation of the Constituents of Nypa Fruticans Wurmb Leaves}

Samples of Nypa fruticans Wurmb were obtained from the bank of Marine Base Waterside ( $4^{\circ} 46^{\prime} 7^{\prime \prime} \mathrm{N}, 7^{\circ} 3$ ' 48" E), Port Harcourt, Rivers State, South-South Nigeria. The fresh long leaves were cut to shorter lengths of about 5 to $8 \mathrm{~cm}$, washed thoroughly in deionized water to remove soil impurities, sun-dried and milled to powder $(500 \mu \mathrm{m}) .1315 \mathrm{~g}$ of the ground powder was extracted by soaking in $70 \%$ aqueous acetone at room temperature. The flasks were properly corked and allowed to stand for 72 hours with occasional shaking. The resulting mixture was filtered with Whatman filter paper (grade 542). The process was repeated for 4 days and the aqueous solvent evaporated to dryness, leaving 209.4 grams of a sticky dark brown residue.

The undesired constituents such as carbohydrates and proteins in the crude extract were separated by dissolving the extract in water, because both carbohydrates and proteins are completely soluble in water $[26,27] .80 \mathrm{~g}$ of the residue was fractionated (successive differential extraction) with Soxhlet apparatus using first, hexane at $340 \mathrm{~K}-343 \mathrm{~K}$, followed by ethyl acetate at $348 \mathrm{~K}-350 \mathrm{~K}$, acetone at $327 \mathrm{~K}-329 \mathrm{~K}$ and methanol at $336 \mathrm{~K}-338 \mathrm{~K}$. On evaporation of the solvents, $10.6756 \mathrm{~g}$ of dark green viscous oil, $10.6235 \mathrm{~g}$ of dark green amorphous solid, $16.7246 \mathrm{~g}$ of greenish yellow solid and
19.4730 g of a dark red solid were obtained for hexane, ethyl acetate, acetone and methanol, respectively. Phytochemical analyses of the sticky dark brown residue and the greenish yellow solid (from differential extraction with acetone at $329 \mathrm{~K}$ ) were conducted according to the methods described in Yadav and Agarwala, 2011 [28]; and Sabri et al., 2012 [29] to obtain the flavonoid used.

\subsection{Preparation of Different Concentrations of the Flavonoid in Sulphuric Acid Solutions}

$0.5 \mathrm{~g}$ of the flavonoid was dissolved in $50 \mathrm{~cm}^{3}$ of ethanol in a beaker and then added to 1 Litre volumetric flasks containing $900 \mathrm{~cm}^{3}$ of $0.1 \mathrm{M}$ sulphuric acid solution. This was made up to the $1000 \mathrm{~cm}^{3}$ with the same acid solution to give $0.5 \mathrm{~g} / \mathrm{L}$ of the solution. This formed the stock solution from which $0.1,0.2$, 0.3 , and $0.4 \mathrm{~g} / \mathrm{L}$ of the solution that was used as test solutions were prepared.

\subsection{Corrosion Experiment: Weight Loss Method}

The different concentrations of the flavonoid prepared in $0.1 \mathrm{M} \mathrm{H}_{2} \mathrm{SO}_{4}$ solution $(0.1 \mathrm{~g} / \mathrm{L}, 0.2 \mathrm{~g} / \mathrm{L}, 0.3 \mathrm{~g} / \mathrm{L}, 0.4 \mathrm{~g} / \mathrm{L}$ and $0.5 \mathrm{~g} / \mathrm{L}$ ) were measured into five out of six separate beakers maintained at 303, 313, 323, 333 and $353 \mathrm{~K}$ in a J.P. SELECTA 6001197 water bath. The sixth beaker is the control experiment. Previously weighed mild steel coupons were then immersed into the test solutions. Each coupon was retrieved after 24 hours progressively for 7 days. The initial and final weights of the dry coupons were taken in grams using a RADWAG AS 220/C/2 analytical weighing balance. The difference in weight of the coupons before and after immersion was taken as the weight loss and recorded. The inhibition efficiencies of the flavonoid (catechin) were calculated using the formula [30],

$$
\% \mathrm{I} . \mathrm{E}=\left(1-\mathrm{W}_{1} / \mathrm{W}_{2}\right) \times 100
$$

Where $\mathrm{W}_{1}$ and $\mathrm{W}_{2}$ are the weight losses in grams for mild steel in the presence and absence of the flavonoids from Nypa fruticans Wurmb leaves extract, in the sulphuric acid $\left(\mathrm{H}_{2} \mathrm{SO}_{4}\right)$ solution at a particular temperature.

The corrosion rate in mils penetration per year (mpy) of mild steel in the different corrosion media was determined from the weight loss using the formula [22],

$$
\text { Corrosion Rate, } \mathrm{C}_{\mathrm{R}}(\mathrm{mpy})=534 \mathrm{w} / \mathrm{DAT}
$$

Where $\mathrm{w}=$ weight loss $(\mathrm{mg}), \mathrm{D}=$ density of specimen $(\mathrm{g}$ $\left./ \mathrm{cm}^{3}\right), \mathrm{A}=$ surface area of specimen $\left(\mathrm{cm}^{2}\right)$ and $\mathrm{T}=$ exposure time (hours).

\section{Results and Discussion}

\subsection{Phytochemical Result for Acetone Constituent}

Flavonoid - Catechin: This belongs to the group of flavonoids called flavanols. The presence of heteroatoms and double bonds make them electron rich and are able to effectively inhibit corrosion by providing sites of adsorption 
unto the metal surface.

Table 1. Phytochemical Result for Acetone Constituent

\begin{tabular}{ll}
\hline Test & Result \\
\hline Alkaloids & - \\
Cardiac Glycosides & - \\
Flavonoids & + \\
Saponins & - \\
Steroids & - \\
Tannins & - \\
Terpenes/ & \\
Terpenoids & - \\
Phenols & + \\
Proteins & - \\
Carbohydrates & - \\
\hline
\end{tabular}<smiles>Oc1cc(O)c2c(c1)O[C@H](c1ccc(O)c(O)c1)[C@H](O)C2</smiles>

Figure 1. Flavonoid separated from Nypa fruticans Wurmb leaves extract (Catechin)

\subsection{Effect of Flavonoid (Catechin) on the Corrosion of Mild Steel in Sulphuric Acid Solution}

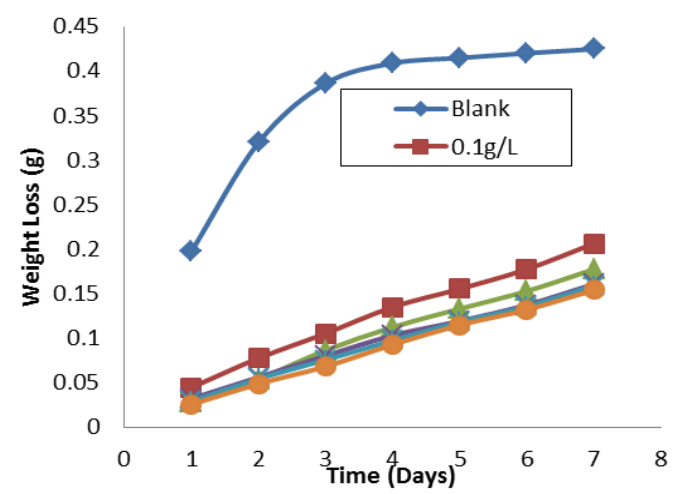

Figure 2. Variation of weight loss (gram) with time with different concentrations of the flavonoid in $0.1 \mathrm{M} \mathrm{H}_{2} \mathrm{SO}_{4}$ at $303 \mathrm{~K}$.

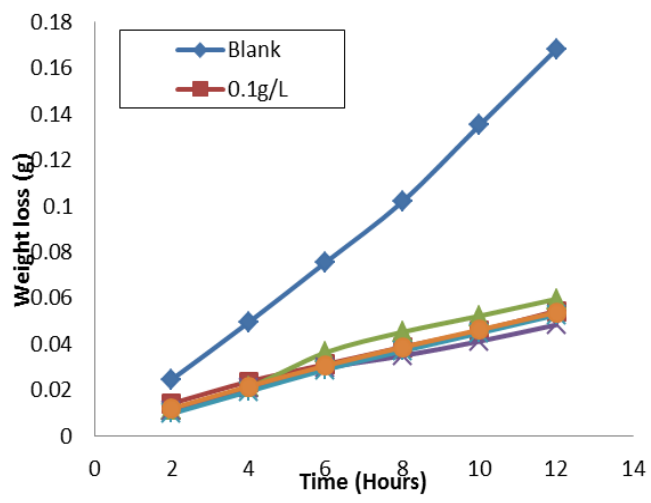

Figure 3. Variation of weight loss (gram) with time with different concentrations of the flavonoid in $0.1 \mathrm{M} \mathrm{H}_{2} \mathrm{SO}_{4}$ at $313 \mathrm{~K}$.

The weight loss of mild steel coupons significantly decreased when the flavonoid from of Nypa fruticans Wurmb leaves extract was added to the corrodent, when compared to a corrodent without an additive (blank), as shown Figure 2. It is believed that the additive (inhibitor) provided the electrons for reduction of $\mathrm{H}^{+}$to hydrogen gas through the double bonds and heteroatoms. This inhibitor reduced corrosion by adsorbing on the metal surface $[31,32]$, protecting the surface by forming a barrier film on the surface. Its adsorption reduced the diffusion or movement of ions to the metallic surface, as well as the ionization of the metal [33]. Figures $3-6$ showed that there was corrosion inhibition even at elevated temperatures of $313 \mathrm{~K}, 323 \mathrm{~K}, 333 \mathrm{~K}$ and $353 \mathrm{~K}$.

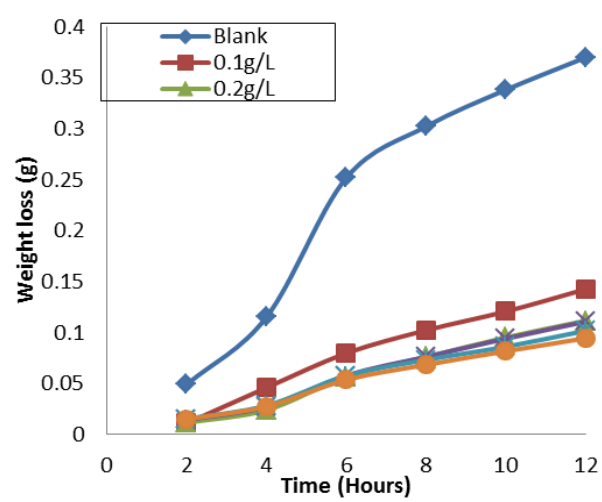

Figure 4. Variation of weight loss (gram) with time with different concentrations of the flavonoid in $0.1 \mathrm{M} \mathrm{H} 2 \mathrm{SO} 4$ at $323 \mathrm{~K}$.

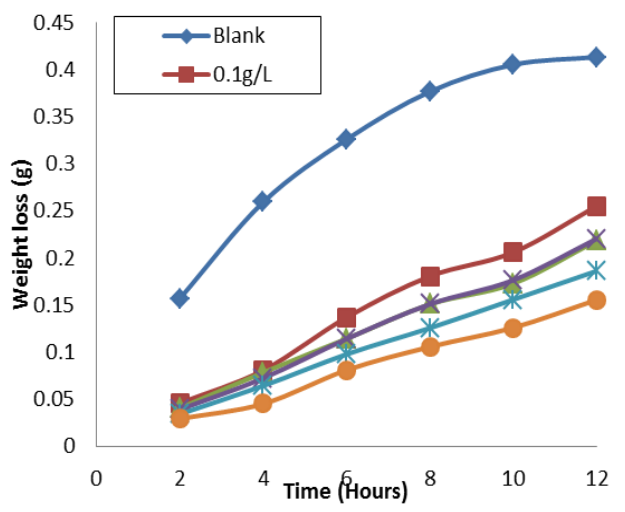

Figure 5. Variation of weight loss (gram) with time with different concentrations of the flavonoid in $0.1 \mathrm{M} \mathrm{H}_{2} \mathrm{SO}_{4}$ at $333 \mathrm{~K}$.

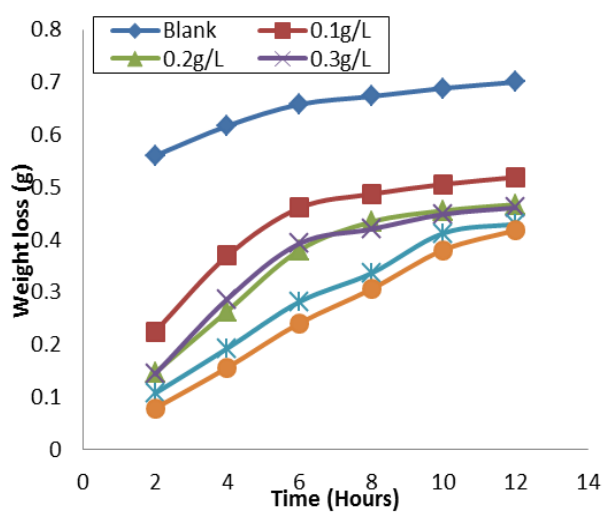

Figure 6. Variation of weight loss (gram) with time with different concentrations of the flavonoid in $0.1 \mathrm{M} \mathrm{H}_{2} \mathrm{SO}_{4}$ at $353 \mathrm{~K}$. 


\subsection{Effect of Inhibitor Concentration on Inhibition Efficiency of the Flavonoid}

Figures 2 - 6 also showed that inhibitor concentration affect weight loss. The highest concentration of the flavonoid $(0.5$ $\mathrm{g} / \mathrm{L}$ ) gave the least weight loss while the least concentration of the inhibitor $(0.1 \mathrm{~g} / \mathrm{L})$, gave the highest weight loss at all temperatures studied. Thus, an increase in the concentrations of the inhibitor increased the adsorption of the inhibitor molecules on the metal and reduced its weight loss. This therefore, leads to higher corrosion inhibition efficiency. Similar observation has been reported [1, 24, 25, 34].

\subsection{Effect of Temperature on Inhibition Efficiency of the Flavonoid}

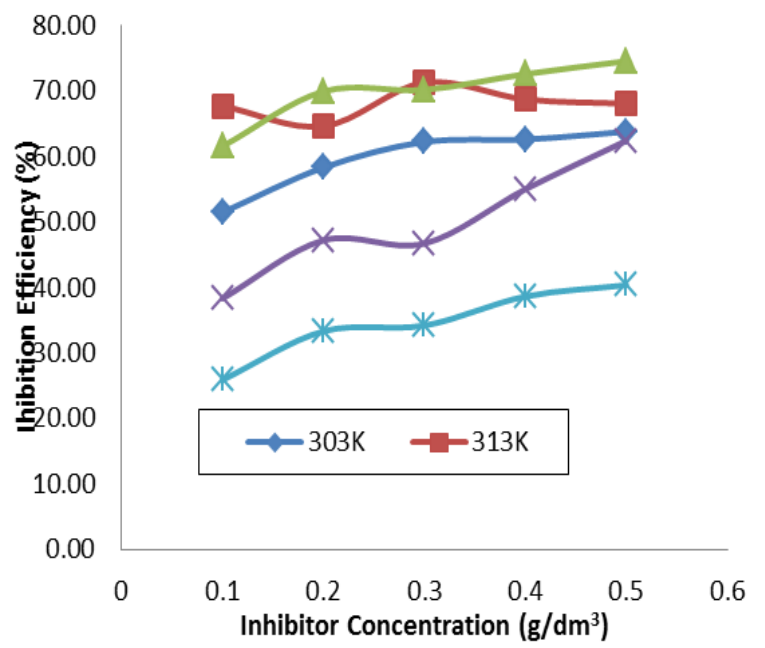

Figure 7. Variation of Inhibition Efficiency with Inhibitor concentration in $0.1 \mathrm{M} \mathrm{H}_{2} \mathrm{SO}_{4}$ at different temperatures.

From figures 7 and 8 , it could be clearly seen that temperature changes also affect the inhibition efficiency of the flavonoid and consequently, the corrosion rates of the metal in the acid solution. Inhibition efficiency increased as temperature increased from $303 \mathrm{~K}$ to $323 \mathrm{~K}$ and began to decrease as temperature was further increased to $333 \mathrm{~K}$ and $353 \mathrm{~K}$. Best corrosion inhibition efficiency of $74.48 \%$ was achieved at $323 \mathrm{~K}$. A similar trend was reported earlier [25]. This observation deviates from the observations made in [23] and in [10], where the percentage corrosion inhibition efficiencies decreased as the temperature increased from $303 \mathrm{~K}$ to $323 \mathrm{~K}$. This deviation in trend might be due to the purer nature of the flavonoid achieved by the separation and the phytochemical analysis of the Nipa wurmb constituents. The increase in the percentage inhibition efficiency may also be attributed to a change in adsorption type from physisorption to chemisorption as temperature is increased [35]. The drop in inhibition efficiency at $333 \mathrm{~K}$ and $353 \mathrm{~K}$, as observed, could be due to solubility of the protective films on the mild steel surface as temperature increased, which increased the metal corrosion $[31,36]$.

The high percentage corrosion inhibition efficiency results in reduced corrosion rates, as shown in figure 8 .

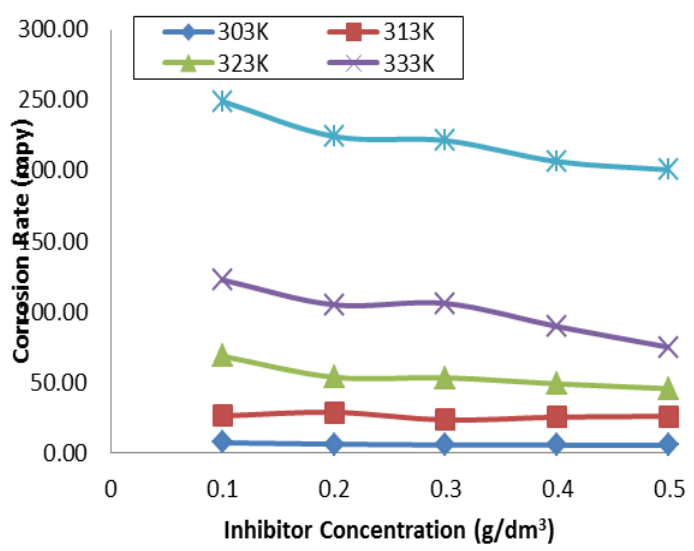

Figure 8. Variation of corrosion rate with Inhibitor concentration in $0.1 M$ $\mathrm{H}_{2} \mathrm{SO}_{4}$ at different temperatures.

The thermal stability of the flavonoid observed at high temperature $(323 \mathrm{~K})$ may be as a result of its structure (Figure $1)$. The presence of benzene rings confers on it, an increased stability [37].

\section{Conclusion}

From the study, it can be concluded that flavonoid catechin, separated from Nypa fruticans Wurmb leaves extract by differential extraction, can be used as a purer, safe, environment friendly and efficient corrosion inhibitor of mild steel in sulphuric acid at $303 \mathrm{~K}, 313 \mathrm{~K}, 323 \mathrm{~K}, 333 \mathrm{~K}$ and $353 \mathrm{~K}$. Since the flavonoid is a purer inhibitor when compared with the crude extract, it can be used in special systems to achieve effective corrosion inhibition of mild steel in acid media at elevated temperature.

\section{References}

[1] Ebenso, E. E., Eddy, N. O. and Odiongenyi, A. O., "Corrosion Inhibitive Properties and Adsorption Behaviour of Ethanol Extract of Piper guinensis as a Green Corrosion Inhibitor for Mild Steel in $\mathrm{H}_{2} \mathrm{SO}_{4}$ ". African Journal of Pure and Applied Chemistry, 2008, (11): 107-115.

[2] Abiola, O. K. and James, A. O., "The Effects of Aloe Vera Extract on Corrosion and Kinetics of Corrosion Process of Zinc in HCl Solution”. Corrosion Science, 2010, 52: 661-664.

[3] Abiola, O. K., Otaigbe, J. O .E. and Kio, O. A., "Gossopium hirsutum L. Extract as Green Corrosion Inhibitor for Aluminium in $\mathrm{NaOH}$ Solution". Corrosion Science, 2009, 51: $1879-1881$.

[4] Abiola O. K., Oforka N. C., Ebenso E. E., Nwinuka N. M. "Eco - friendly Corrosion Inhibitors: Inhibitive action of Delonix regia Extract for the Corrosion of Aluminium in Acidic Medium”. Anti-Corrosion Methods \& Materials, 2007, 54: 219-224.

[5] Oguzie, E. E., "Corrosion Inhibitive Effect and Adsorption Behaviour of Hibiscus sabdariffa Extract on Mild Steel in Acidic Media." Portugaliae Electrochimica Acta, 2008, 26(3): 303-314. 
[6] James, A.O. and Etela, A.O., "Aloe Vera: An Inhibitor of Aluminum Corrosion in Hydrochloric Acid". Journal of Pure \& Applied Chemistry, 2008, 3(3): $141-145$.

[7] Kalada, H. and James, A.O., "The Inhibitive Effect of Aloe Vera Barbadensis Gel on Copper in Hydrochloric Acid Medium." Journal of Emerging Trends in Engineering and Applied Sciences, 2014, 5(1): 24-29.

[8] Sribharathy, V. and Rajendran, S., "Cuminum cyminum Extracts as Eco-Friendly Corrosion Inhibitor for Mild Steel in Seawater." Hindawi Publishing Corporation, ISRN Corrosion, Volume 2013, Article ID 370802: 1 - 7.

[9] Fouda, A. S., Tawfik, H., and Badr, A. H. "Corrosion Inhibition of Mild Steel by Camellia sinensis Extract as Green Inhibitor". Advances in Materials and Corrosion 2012, 1: 1-21.

[10] Orubite-Okorosaye, K, Jack, I. R, Ochei, M., Akaranta, O., "Synergistic Effect of Potassium Iodide on Corrosion Inhibition of Mild Steel in $\mathrm{HCl}$ Medium by Extracts of Nypa Fruticans Wurmb." Journal of Applied Science and Environmental Management, 2007, 11(2): 27-31.

[11] Omotosho, O. A., Ajayi, O. O, Ajanaku, K. O., Ifepe, V. O., "Environment Induced Failure of Mild Steel in 2 M Sulphuric Acid Using Chromolaena odorata." Journal of Material and Environmental Science, 2012, 3(1): 66 - 75.

[12] Vimala, J. R., Leema, A. R., Raja, S., "Cassia auriculata Extract as Corrosion Inhibitor for Mild Steel in Acid medium." International Journal of ChemTech Research, 2011, 3(4): 1791 -1801 .

[13] Avwiri, G. O. and Osarolube, E., "Inhibitive Action of Aloe Vera on the Corrosion of Copper and Brass in different media." Scientia Africana, 2010, 9(2): 51-58.

[14] Ranchman, A. K. and Sudarto, Y. (1992). "Nipah: Sumber Pemanis Baru", Kanisius Edition, Yogyakarta Publishers, Indonesia, pp. 44.

[15] Teo, S., Ang, W. F., Lok, A. F. S. L., Kurukulasuriya, B. R. and Tan, H. T. W. (2010). "Status and Distribution of Nypa fruticans in Singapore." Nature in Singapore: 45 - 52 .

[16] Halos, S.C. "Nypa for Alcogas Production.” Canopy, 1981, $7: 51-56$

[17] Le-Thi, T. H., Nguyen, X. V., Le-Thi, T. T., "Guidelines: Taking Care, Harvesting and Processing Sugar and Alcohol from Nypa Palm's Sap." A Publication by the Institute of Oceanography, Vietnam, through: The Rufford Small Grants Foundation, 2007.

[18] Wankasi, D., Horsfall, M. J., Spiff, A. I., "Desorption of $\mathrm{Pb}^{2+}$ and $\mathrm{Cu}^{2+}$ from Nipa palm (Nypa fruticans Wurmb) biomass." African Journal of Biotechnology, 2005, 4: 923 - 927.

[19] Sunderland, T. C. H. and Murakinyo, T., "Nypa fruticans, A Weed in West Africa"; PALMS, 2002, 46(3), 154 - 155.

[20] Ukoima, H. N., "Biodiversity Reservation of Nypah Palm Extermination or Utilization": A paper presented at the 7th annual conference of Nigerian Society of Biological Conservation, Held in Rivers State University of Science and Technology, Port Hacourt, Nigeria, 2000.

[21] Udofia, S. I and Udo, E. S. (2005). "Local Knowledge of the Utilization of Nipa Palm (Nypa fruticans, Wurmb) in the Coastal Areas of Akwa Ibom State, Nigeria." Global Journal of
Agricultural Science, 4: $33-40$.

[22] Orubite-Okorosaye, K. and Oforka, N. C.. "Corrosion Inhibition of Zinc on $\mathrm{HCl}$ using Nypa fruticans Wurmb Extract and 1,5 Diphenyl Carbazone." Journal of Applied Science and Environmental Management, 2004, 8(1): 57 - 61.

[23] Orubite, O. K. and Oforka, N. C. (2004). "Inhibition of the Corrosion of Mild Steel in Hydrochloric Acid Solutions by the Extracts of Leaves of Nypa fruticans Wurmb." Material Letters, 2004 58(11): 1768-1772.

[24] Mohd-Zaidi, M. S., Mohd-Farhan, M. N., Mohd-Wahid, S., Mohamed, R. O. (2012). "Corrosion Inhibition of Aluminum by Using Nipah (Nypa Fruticans) Extract Solutions in Hydrochloric Acid ( $\mathrm{HCl})$ Media", International Journal of Electrochemical Science, 2012, 7: 1958 - 1967.

[25] James, A.O., Akaranta, O., Awatefe, K.J. (2011). "Red Peanut Skin: An Excellent Green Inhibitor for Mild Steel Dissolution in Hydrochloric Acid Solution." Alfa Universal - An International Journal of Chemistry, 2011 2,(2): 133 - 139.

[26] Cannell, R. J. P. (Ed.), "Natural Products Isolation", Humana Press Inc, Totowa, New Jersey, 1998, pp. $343-380$.

[27] Sarker, S. D., Latif, Z., Gray, I. A., "Natural Product Isolation", Second Edition, Humana Press Inc., Totowa, New Jersey, 2006 pp. $323-391$.

[28] Yadav, R. N. S. and Argawala, M., "Phytochemical Analysis of Some Medicinal Plants." Journal of Phytology, 2011, 3(12): 10 -14 .

[29] Sabri, F. Z., Belarbi, M., Sabri, S., Alsayadi, M. M. S., "Phytochemical Screening and Identification of Some Compounds from Mallow." Scholars Research Library, Journal of Natural Products and Plant Resources, 2012, 2 (4):512-516.

[30] Ekpe, U. J., Ebenso, E. E., Ibok, U. J. "Inhibitory action of Azadirachta indica Leaves Extract on Corrosion of Mild Steel in Tetraoxosulphate (vi) Acid Dissolution of Metals". Journal West African Science Associations, 1994, 37: 13-30.

[31] James, A.O., Oforka, N.C., Abiola, O.K. and Ita, B.I., "Corrosion Inhibition of Mild Steel in Hydrochloric Acid by 2-Benzoylpyridine and Pyridoxolhydrochloride", CODEN ECJHAO E-Journal of Chemistry, 2009, 6(2): 385-394.

[32] Abiola, O. K. and Otaigbe, J. O. E., "Adsorption Behaviour of 1-phenyl-3-methylpyrazol-5-one on Mild Steel from HCI Solution", International Journal of Electrochemical Science, 2008, 3:191-198.

[33] NACE (2000). "Corrosion Information Module". NACE Resource Centre, Houston, Texas. Availabele from: http//www.nace.org/corrosion. Retrieved: 4/12/2013.

[34] Popoola, A.P.I and Fayomi, O.S., "Environmental failure of $2 \mathrm{M}$ acid Strength on Zinc Electroplated Mild Steel in the Presence of Nicotiana Tobacum". Scientific Research and Essays, 2011, 6(14): 3079 - 3088.

[35] Atkins, P.W. and De Paula, J., "Atkins' Physical Chemistry"; Eight Edition (International Student Edition), Oxford Press, Oxford, 2006, pp. 909-923.

[36] Okafor P. C., Ebenso E. E., Ekpe U. J., "Azadirachta indica Extracts as Corrosion Inhibitor for Mild Steel in Acid Medium", International Journal of Electrochemical Science, 2010, (5): 978-993. 

Solution by Flavonoid (Catechin) Separated from Nypa Fruticans Wurmb Leaves Extract

[37] Liu, S. X. and White, E., "Extraction and Characterization of Proanthocyanidins from Grape Seeds". The Open Food Science Journal, 2012, 6: 5-11. 